\title{
PROFIEL EN BETROKKENHEID VAN AFGETREDE VRYWILLIGERS BY 'N NIE-WINSGEWENDE ORGANISASIE
}

\section{Sanet Jansen van Rensburg, Herman Strydom}

\section{INLEIDING}

In hierdie artikel word daar gefokus op die betrokkenheid van afgetrede vrywilligers by 'n spesifieke nie-winsgewende organisasie, naamlik die Potchefstroom Dienssentrum vir Bejaardes. Daar word gepoog om 'n profiel van afgetrede vrywilligers van hierdie organisasie saam te stel, die terreine waarop hulle betrokke is, te ondersoek, asook om die mate van verantwoordelikheid te bepaal wat hulle bereid is om te aanvaar. Die verwagtinge wat vrywilligers van die organisasie koester en die betekenis van vrywillige werk vir die afgetrede vrywilliger self, word ook ondersoek.

\section{PROBLEEMSTELLING}

Volgens die Oktober 1996-sensusopname het Suid-Afrika 40.5 miljoen inwoners gehad van wie $6.9 \%$ ouer as 60 jaar was. Die 2001-sensusopname bevestig dat daar $7.3 \%$ (3.28 miljoen) uit 'n bevolking van 44.8 miljoen ouer as 60 jaar was; dus 'n toename van $0.4 \%$ (Department of Social Development, 2005:11). Ntusi en Ferreira (2004:3) voorspel dat die 80-jariges en ouer se persentasie van $8 \%$ in 2002 na $19 \%$ in 2050 gaan verdubbel. In die Noordwes Provinsie was daar in $19967.9 \%$ persone ouer as 60 jaar (224 010 persone) teenoor 2001 se 8.2\% (269 500 persone); dus 'n aanwas van $0.3 \%$ in 4 jaar. Nagenoeg 10403 persone ouer as 60 jaar is in Potchefstroom woonagtig (Statistics South Africa, 2001).

Die huidige ontwikkeling van mense se vermoëns neig in die rigting van groter selfonderhoud binne 'n ondersteunende en versorgende omgewing. 'n Merkbare klemverskuiwing het plaasgevind - weg van residensiële versorging na gemeenskapsversorging. Dit beteken dat slegs die erg verswakte bejaardes na inrigtings verskuif sal word (Van der Linde, 1996:1). Al die ander ouer persone moet in die gemeenskap versorg word. Dienssentrums het ten doel om alle noodsaaklike ondersteunende hulpdienste te lewer en ontspanningsgeleenthede te skep wat die senior burger in staat stel om solank moontlik sinvol, selfstandig, onafhanklik en menswaardig in die gemeenskap aan te bly, dit wil sê in sy eie huis of woonstel en dus buite 'n tehuis vir bejaardes (Van den Heever, 1990). Gedurende 1995 was daar 385 geregistreerde dienssentrums vir bejaardes in Suid-Afrika, terwyl daar in 1998 slegs 188 was (Department of Social Development, 2005:45).

Vrywilligers is mense wat sonder finansiële vergoeding hul tyd, kennis en vermoëns beskikbaar stel vir die bevordering van 'n bepaalde saak (Krüger, 2008:18). Die betrokkenheid van vrywilligers laat hulle nuttig, diensbaar en gewaardeerd voel te midde van selfvertroue wat dikwels met veroudering 'n knou kry; hulle bly op hoogte van die jongste verwikkelinge, hulle is minder eensaam en hulle aanvaar eienaarskap van die dienssentrum (Eckley, 2007; Van den Heever, 1990:1). Uit 'n studie van Van Zyl (1992) blyk gevoelens na aftrede die volgende te wees: die individue het daarna uitgesien, hulle beleef 'n gevoel van verligting en minder spanning, maar ook negatiewe gevoelens soos onsekerheid, leegheid, doelloosheid en 'n soeke na die self. Die vier dinge wat 'n afgetrede persoon nodig het, aldus Stim en Warner (2008), is geld, goeie gesondheid, 'n netwerk van familie en vriende en betrokkenheid by aktiwiteite wat genot kan verskaf. Kulik (2006) se studie het ook uitgewys dat uitbranding minder by 
vrywilligers as by persone wat selfgesentreerd leef, voorkom as gevolg van die feit dat hulle uit vrye wil betrokke is by 'n saak waarin hulle belangstel en waartoe hulle 'n bydrae wil lewer.

Wheeler et al. (1998) bevestig die belangrike rol van vrywilligers en hul betrokkenheid by die hedendaagse gemeenskap. Leeson (2006) en Van der Linde (2007) meld dat afgetredenes die rykste bron van vrywilligers is en oor 'n leeftyd se kennis en lewenservaring beskik, terwyl hulle ook meer vrye tyd as ander persone beskikbaar het en dikwels 'n gevoel beleef om iets aan die gemeenskap terug te gee. Vrywillige betrokkenheid bied addisionele mannekrag in 'n tyd van toenemende vermindering in welsynsbegroting en die toenemende maatskaplike nood van die bevolking. Deur vrywilligers se betrokkenheid is dit moontlik om gemeenskapsdienste beskikbaar te stel wat die regering nie in staat is om te lewer nie en kan vrywilligers die professionele personeel aanvul en bystaan met dienste en take wat nie-professionele vaardighede vereis nie. Daries (1999:119) brei verder hierop uit deur te vermeld dat vrywilligers die betaalde personeel tyd bespaar, dat hulle 'n verlengstuk van hulpbronne is, en dat hulle meer persoonlike aandag aan ouer persone kan bestee vanweë die feit dat hulle meer tyd tot hulle beskikking het as die betaalde personeel. Hierbenewens kan hulle ook hul lewenservaring met hulle deel.

Golden (1991:231), Potchefstroom Dienssentrum vir Bejaardes (2008c), Rörich (1992:171), Roux (2008:1) en Slabbert (1989:143-144) noem die eienskappe waaroor vrywilligers behoort te beskik, naamlik dat hulle:

- nie by die verwerking van 'n persoonlike lewenskrisis betrokke moet wees nie en emosioneel stabiel moet wees;

- vriendelikheid, opregtheid, aanpasbaarheid, selfhandhawing en 'n positiewe gesindheid moet openbaar;

- geduld, deursettingsvermoë, betroubaarheid en pligsgetrouheid aan die dag moet lê;

- nie te persoonlik by ander se probleme betrokke moet raak nie;

- belangstelling, begrip en empatie moet toon;

- goeie interpersoonlike verhoudings moet handhaaf en oor goeie kommunikasievaardighede moet beskik;

- 'n verantwoordelikheidsbesef moet hê en gemotiveerdheid moet wees;

- vertroulikheid moet kan handhaaf en in die moontlikhede van mense moet glo;

- met ander in 'n span moet kan saamwerk, en

- lojaal teenoor die organisasie en die kliënte moet wees.

Die eienskappe wat die sterkste uit bogenoemde outeurs se standpunte na vore kom, is betroubaarheid, vriendelikheid, aanpasbaarheid, empatie, selfhandhawing, verantwoordelikheid en kommunikasievaardighede. Myburgh (1999:84) meld dat navorsing bewys het dat al hoe meer ouer werknemers in die praktyk uitmunt ten opsigte van hulle kennis, ervaring, vaardighede en kliëntgeoriënteerdheid. Ouer werknemers is oor die algemeen emosioneel meer stabiel en aanpasbaar en goeie hanteerders van krisisse. Hulle is meer betroubaar en toegewyd en hulle ervaring gee hulle dikwels die agtergrond om komplekse take makliker uit te voer.

Vrywilligers kan moontlik verhoudingsprobleme ondervind met diegene wat van hul dienste gebruik maak. Hulle kan dit dalk byvoorbeeld moeilik vind om met kliënte oor die weg te kom wat moeilik is of wat eise stel of met die afsterwe van kliënte. Dit kan vrywilligers moontlik frustreer of nutteloos laat voel, of dit kan daartoe lei dat hulle angstigheid en selfs depressie 
beleef, wat weer uitbranding tot gevolg kan hê (Haski-Levinthal, 2001; Lehrman-Abarbanel, 1994). Ten einde afgetrede vrywilligers se langtermynbetrokkenheid by die organisasie te verseker is dit belangrik om hul vaardighede en talente te ken en bewus te wees van hul verwagtinge van die organisasie. Opleiding van vrywilligers en die korrekte plasing van 'n vrywilliger by 'n spesifieke afdeling van die dienssentrum en by 'n bepaalde personeellid is belangrik ten einde die beste passing te bewerkstellig en die beste resultate vir die organisasie te bereik.

Die volgende navorsingsvrae kan gestel word: Wat is die profiel van afgetrede vrywilligers by hierdie spesifieke nie-winsgewende organisasie, op watter terreine is hulle betrokke, wat is die mate van verantwoordelikheid wat hulle bereid is om te aanvaar, wat is hul verwagtinge van die organisasie en wat beteken vrywillige werk vir hulle?

\section{DOEL VAN DIE ONDERSOEK}

Die oorhoofse doelstelling van die ondersoek is om sekere aspekte van die afgetrede vrywilliger by hierdie spesifieke nie-winsgewende organisasie te ondersoek soos bv 'n profiel van afgetrede vrywilligers, die diensleweringsterreine waarop hulle betrokke is, die mate van verantwoordelikheid wat hul bereid is om te aanvaar, hul verwagtinge en die betekenis van vrywillige werk vir deelnemers.

Ten einde bogenoemde doelstelling te bereik is die volgende doelwitte nagestreef:

- Om 'n profiel van die afgetrede vrywilliger by hierdie spesifieke nie-winsgewende organisasie te bepaal;

- Om die diensleweringsterreine waarop hulle betrokke is, te omlyn;

- Om die mate van verantwoordelikheid wat hulle bereid is om te aanvaar vas te stel;

- Om hulle verwagtinge van die organisasie te omlyn, en

- Om die betekenis van vrywillige werk vir deelnemers aan hierdie ondersoek te bepaal.

\section{NAVORSINGSMETODOLOGIE}

Volgens Burns en Grove (2005:211) vorm die navorsingsontwerp die strukturele raamwerk van die studie. Die ontwerp van hierdie studie word uitgebou ooreenkomstig die benadering gemengde metodologie en spesifiek die gelyktydig geïntegreerde strategie (Creswell, 2009:214-215). Die verkennende ontwerp word benut omdat min navorsing op hierdie gebied gedoen is en om meer agtergrond ten opsigte van die situasie te verkry (Grinnell \& Unrau, 2008: 192; 2001:29; Mitchell \& Jolley, 2001:G-3; Neuman, 2006:33-34; Rubin \& Babbie, 2005:123-124).

Potchefstroom Dienssentrum vir Bejaardes is die grootste outonome nie-winsgewende welsynsorganisasie in Potchefstroom met 'n totaal van 132 vrywillige werkers. Die onderhawige ondersoek het betrekking op manlike en vroulike deelnemers van 60 jaar en ouer. Met behulp van waarskynlikheidseleksie-steekproeftrekking, en spesifiek die sistematiese steekproef, is die teikengroep geselekteer (Strydom, 2005a:200). Daar is besluit om 33\% (44 respondente) afgetrede vrywilligers van Potchefstroom Dienssentrum vir Bejaardes by die ondersoek te betrek (Stoker, 1985). Die name van die bejaardes wat as vrywilligers by Potchefstroom Dienssentrum vir Bejaardes betrokke is, is alfabeties georden. Die tweede persoon op die ranglys is aanvanklik geselekteer en dan verder met intervalle van drie tot die verlangde aantal deelnemers (44 persone) verkry is. 
Data is ingesamel aan die hand van 'n selfopgestelde skedule wat as riglyn in die fokusgroepe benut is (Greeff, 2005:292). Die selfopgestelde skedule bestaan uit oop en geslote vrae wat dus 'n element van beide kwantitatiewe en kwalitatiewe navorsing insluit; vandaar die gemengdemetode-navorsing. Die persone wat by die steekproef betrek is, is telefonies genader ten einde toestemming tot deelname te verkry. Vier fokusgroepe is op hierdie wyse saamgestel, bestaande uit onderskeidelik 6, 13, 13 en 12 deelnemers. Die vier groepsessies het binne 'n tydperk van twee weke plaasgevind ten einde die nodige inligting te bekom.

Etiese goedkeuring is van die Etiekkomitee van die Potchefstroomkampus van die NoordwesUniversiteit verkry met verwysingsnommer NWU-0017-08-S1. Deelnemers is te alle tye met respek behandel, is verseker dat deelname deurentyd vrywillig sou geskied, met ingeligte toestemming en dat hulle hul te eniger tyd aan die ondersoek kon onttrek (Mertens \& Ginsberg, 2009:508). Die werkswyse wat in die fokusgroepe gevolg sou word, is aan die ondersoekgroep verduidelik, naamlik dat hulle 'n eerlike mening oor die vrae moes uitspreek al stem hul nie saam met wat die res van die groep se opvatting is nie en dat alle inligting wat deur lede verstrek sou word, as vertroulik deur groeplede hanteer moet word. Die uiteindelike doel van die ondersoek is ook breedvoerig aan die deelnemers voorgehou, naamlik dat hul deelname en betrokkenheid by die groepe aanleiding kan gee tot die ontwikkeling van 'n doeltreffende program vir vrywillige werkers waardeur die organisasie, die kliënte en die vrywilligers se behoeftes ten beste gedien sal word.

Toestemming om die ondersoek te onderneem is op 11 Februarie 2008 tydens 'n Beheerraadsvergadering van Potchefstroom Dienssentrum vir Bejaardes verkry. Die Beheerraad is ook deurlopend op hoogte gehou rakende die vordering van die navorsing. Die deelnemers is na afloop van die insameling en verwerking van die data volledig oor die bevindings ingelig tydens 'n spesiale geleentheid wat vir alle deelnemers gereël was (Strydom, 2005b:57-67). Die selfopgestelde vraelys wat beide kwalitatiewe en kwantitatiewe inligting bevat, is deur die navorser self ontleed. Die geslote vrae is volgens Tesch se benadering in temas verwerk (Poggenpoel, 1998:343-344).

\section{BEVINDINGE}

Die data word aan die hand van die volgende aspekte hanteer.

\section{- PROFIEL VAN DIE AFGETREDE VRYWILLIGER}

Die profiel word aan die hand van die volgende aspekte behandel.

\section{Geslag}

Vier en dertig (77\%) van die respondente is vroulik en 10 (23\%) manlik. Kulik (2006) se navorsing wat in Israel gedoen is, toon dat, uit 375 vrywilligers, 92 (24.5\%) mans was en 283 (75.5\%) vroue, wat dus die bevindinge van hierdie ondersoek bevestig. Le Roux (1985:114) het navorsing by 25 dienssentrums onderneem wat 'n gemiddeld van 33 vrywilligers elk gehad het wat ouer as 60 jaar was. Die dames was in die meerderheid met $95 \%$ en die oorblywende $5 \%$ was mans. Uit bogenoemde is dit duidelik dat die vroulike geslag meer as die mans as vrywillige werkers betrokke is.

\section{Ouderdom}

Die gemiddelde ouderdom van die respondente is 72 jaar. Die oudste vrywilliger is 87 jaar en die jongste persoon 60 jaar. Daar bestaan 'n verskeidenheid dienste waarby ouer persone by die dienssentrum betrokke kan raak, en dit waarby lede betrokke kan raak, word grootliks bepaal deur hul belangstellings en gesondheidstoestand. 


\section{Taal}

Al 44 deelnemers aan die ondersoek is Afrikaanssprekend. Dit word toegeskryf aan die feit dat Potchefstroom oorwegend Afrikaanssprekend is en die grootste aantal lede van die dienssentrum Afrikaanssprekend is.

\section{Gesin van herkoms}

Die respondente se gesin van herkoms kan soos volg uitgebeeld word:

\section{SEGMENTVOORSTELLING 1 GESIN VAN HERKOMS}

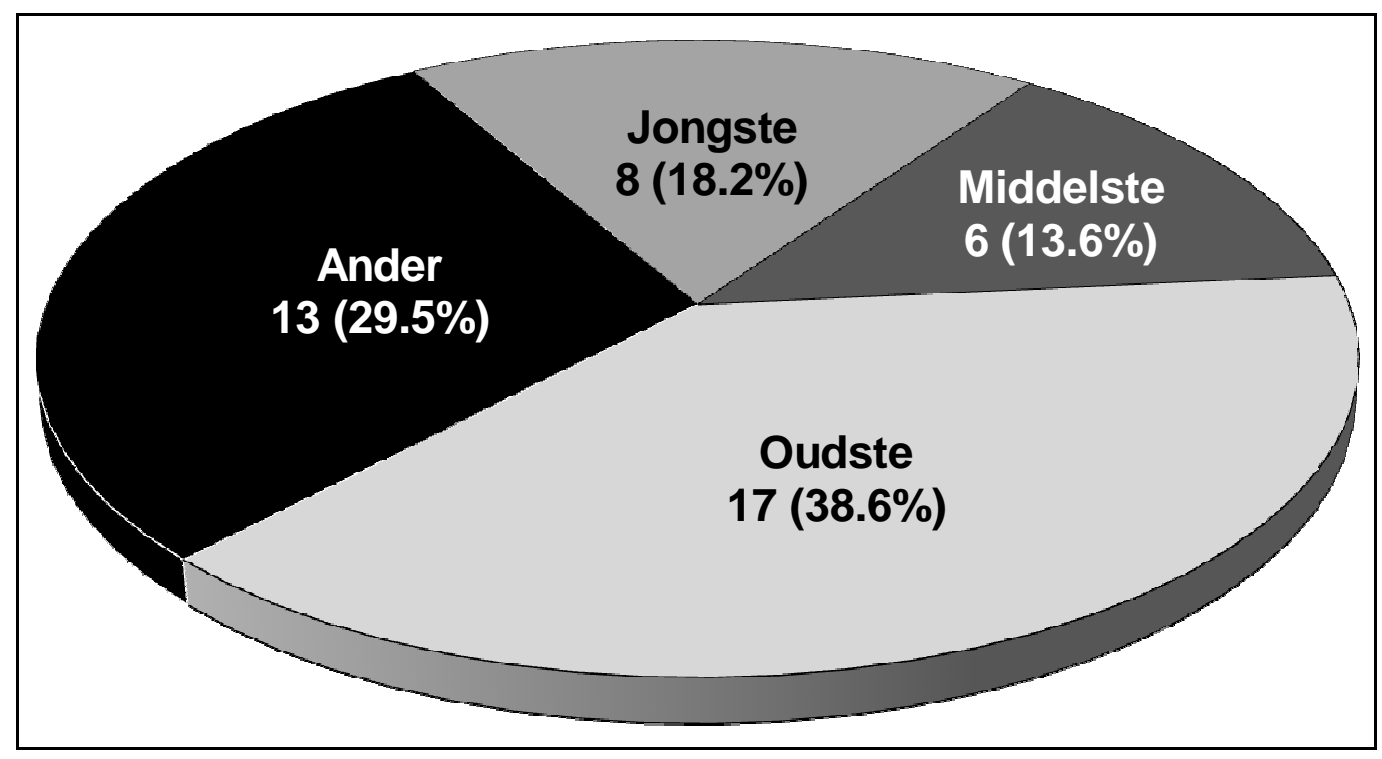

Die respondente was gemiddeld een van vyf kinders uit hul gesin van herkoms. Segmentvoorstelling 1 beeld die posisie in die gesin van die respondente baie duidelik uit. Uit die 44 persone wat betrokke is, was $8(18 \%)$ die jongste; 6 (14\%) die middelste en $17(39 \%)$ die oudste kind. Dertien persone (29\%) het'n ander posisie in die gesin beklee. Dit blyk dus dat die oudste kinders meer betrokke is as dié in enige ander posisie in die gesin, wat moontlik toegeskryf kan word aan die verantwoordelikheidsin wat dikwels onder oudste kinders voorkom.

\section{Kinders}

Gemiddeld het deelnemers drie kinders. Die persoon wat die minste kinders het, het twee en dié wat die meeste het, het 7 . Wat besonder interessant is, is dat daar gemiddeld vyf kinders in hul gesin van herkoms was. Die afname in bevolkingsaanwas met 'n volgende generasie is dus ' $\mathrm{n}$ baie duidelike patroon. Vier en twintig (55\%) van die deelnemers het geen kind wat in Potchefstroom woonagtig is nie. Die res $(45 \%)$ het 'n kind wat in Potchefstroom woon, en vier het ook kinders oorsee. Hierdie vraag is aan deelnemers gestel om vas te stel of vrywilligers by die dienssentrum betrokke is omdat hulle nie kinders het wat in Potchefstroom gevestig is nie. Dit is duidelik dat kinders se teenwoordigheid geen rol by die afgetredenes se betrokkenheid as vrywilligers speel nie.

Verder is deelnemers ook gevra oor hul kinders se reaksie op hul betrokkenheid as vrywilligers en is die volgende standpunte uitgelig:

- Ons kinders voel goed en positief oor ons betrokkenheid by die dienssentrum.

- Die kinders is dankbaar dat ons nog betrokke kan wees en uit die huis kom.

- Ons kinders moedig ons aan om betrokke te raak. 
- Weet nie hoe die kinders voel nie.

Oor die algemeen blyk dit dus dat die kinders van die ouer persone wat as vrywilligers betrokke is, gelukkig en tevrede is met die feit dat hul ouers nog diensbaar wil en kan wees. Dit is ook'n goeie aanduiding vir kinders dat hul ouers nie ophou leef het toe hulle die dag afgetree het nie.

\section{Betrokkenheid in jonger jare}

Uit die vraag oor die werk of aktiwiteit waarby die respondente in hul vroeëre jare betrokke was, het die volgende resultate na vore gekom. (Respondente kon aandui dat hulle by meer as een instansie betrokke was.)

TABEL 1

BETROKKENHEID BY ORGANISASIES OF INSTANSIES

\begin{tabular}{|l|c|c|c|c|c|c|}
\hline ORGANISASIE/INSTANSIE & Ja & \% & Nee & \% & Totaal & $\%$ \\
\hline Welsynsorganisasies & 15 & 34.09 & 29 & 65.91 & 44 & 100 \\
\hline Kerk & 42 & 95.45 & 2 & 4.55 & 44 & 100 \\
\hline Skool & 39 & 88.64 & 5 & 11.36 & 44 & 100 \\
\hline Ander & 19 & 43.18 & 25 & 56.82 & 44 & 100 \\
\hline
\end{tabular}

Uit Tabel 1 kan afgelei word dat vrywilligers vroeër veral by die kerk (95\%) en skool (89\%) betrokke was. Bogenoemde tabel in ag genome, is dit duidelik dat die betrokke deelnemers reeds as jongmense by nie-winsgewende organisasies of instansies as vrywilligers betrokke was. Dit is dus nie vreemd dat hulle hul dienste vir die dienssentrum aanbied nie. Diegene wat die ander-kategorie angedui het, was onder andere betrokke by organisasies soos die Rapportryers, noodhulp, rolbalvereniging, Voortrekkers en Vroue Landbou-Unie.

\section{Beroep voor aftrede}

Die respondente het die volgende beroepe voor aftrede beoefen:

\section{FIGUUR 1}

BEROEP BEOEFEN VOOR AFTREDE

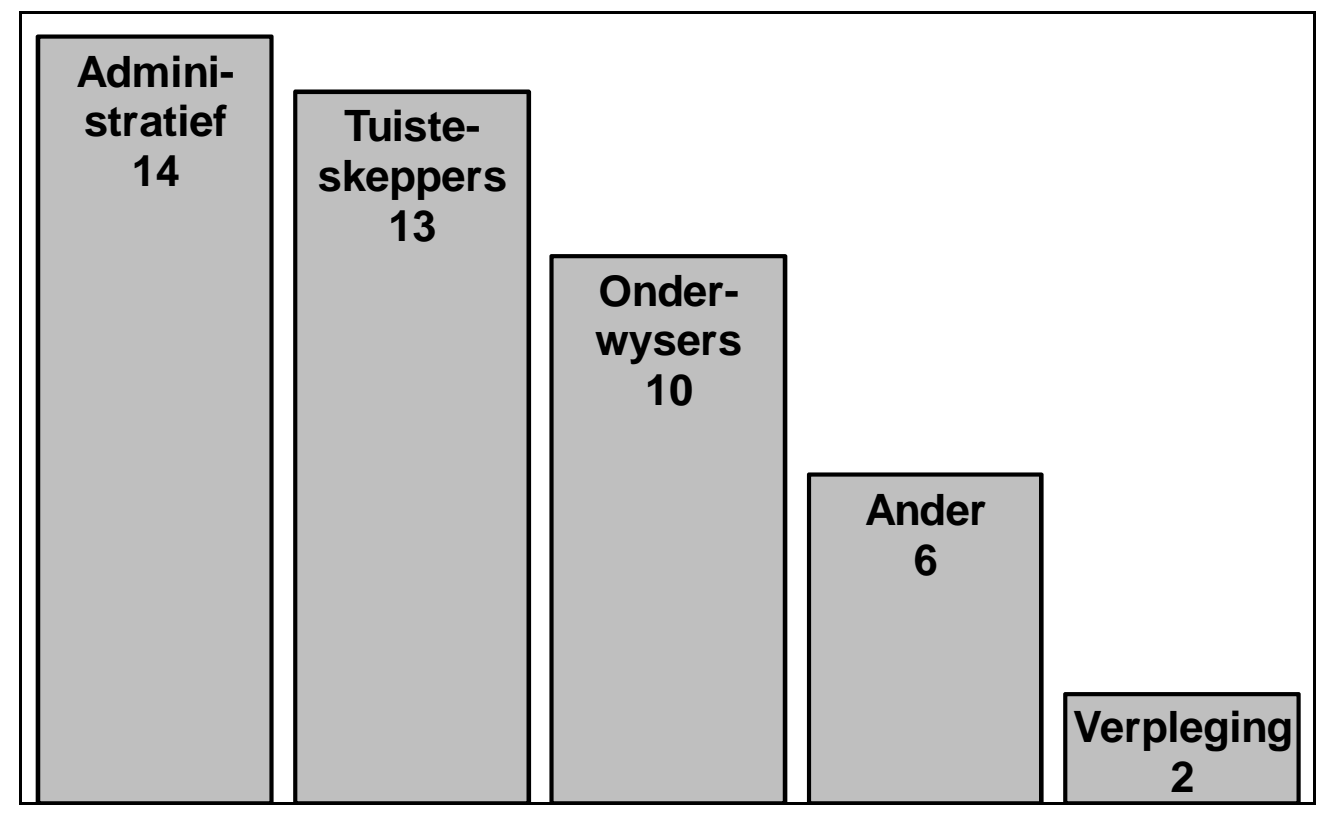


Die meeste vrywilligers was onderskeidelik tuisteskeppers of mense in administratiewe poste. Dan volg nege wat in die onderwys was; ander persone was werksaam as speurder, sakevrou, bestuurder, stadstesourier en ontwerptekenaar, en twee was in die verpleegberoep.

\section{Tydperk van betrokkenheid}

Die meeste respondente het as vrywilligers by die dienssentrum betrokke geraak direk nadat hulle as lede van die dienssentrum aangesluit het.

TABEL 2

TYDPERK VAN BETROKKENHEID BY DIE DIENSSENTRUM

\begin{tabular}{|l|c|c|}
\hline AANTAL JARE & PERSONE & PERSENTASIE \\
\hline $0-5$ jaar & 24 & 54.54 \\
\hline 6-10 jaar & 14 & 32.82 \\
\hline $11-15$ jaar & 3 & 6.82 \\
\hline 16-20 jaar & 3 & 6.82 \\
\hline TOTAAL & $\mathbf{4 4}$ & $\mathbf{1 0 0}$ \\
\hline
\end{tabular}

Uit Tabel 2 blyk dit dat 54\% van die respondente 5 jaar en korter as vrywilligers by die dienssentrum betrokke is en 32\% van die respondente reeds tussen 6 en 10 jaar. Van die 44 respondente is $7 \%$ al tussen 11 en 15 jaar by die dienssentrum as vrywilligers werksaam en 'n ander $7 \%$ reeds tussen 16 en 20 jaar.

Uit die voorafgaande kategorieë waarin die profiel van 'n afgetrede vrywilliger by hierdie betrokke organisasie gerapporteer is, kan die volgende ter samevatting aangedui word. Soos te wagte kon wees, is $77 \%$ van die betrokke vrywilligers vroulik, Afrikaanssprekend, gemiddeld 72 jaar oud, een van vyf kinders uit die gesin van herkoms met 'n gemiddelde van drie kinders uit hul eie huwelik. Feitlik almal was vroeër by die kerk en skool betrokke, het in 'n administratiewe hoedanigheid of as tuisteskepper gewerk. Feitlik 55\% van die deelnemers was ten tye van die ondersoek tussen 0 en 5 jaar as vrywilliger betrokke, alhoewel $32 \%$ tussen 6 en 10 jaar betrokke was.

TABEL 3

DIENSTE, PERSONE EN URE BETROKKE AS VRYWILLIGER

\begin{tabular}{|l|c|c|c|}
\hline TIPE DIENS & $\begin{array}{c}\text { AANTAL } \\
\text { PERSONE }\end{array}$ & $\begin{array}{c}\text { AANTAL URE } \\
\text { PER JAAR }\end{array}$ & $\begin{array}{c}\text { GEMIDDELDE URE } \\
\text { PER PERSOON }\end{array}$ \\
\hline Komitee & 27 & 360 & 13.33 \\
\hline Administrasie & 17 & 126 & 7.41 \\
\hline Maatskaplike werk & 36 & 1209 & 33.58 \\
\hline Aanry-etes & 3 & 24 & 8.00 \\
\hline Etes & 6 & 91 & 15.17 \\
\hline Spyseniering & 71 & 849 & 11.96 \\
\hline Gesondheidsdienste & 1 & 9 & 9.00 \\
\hline Fondswerwingsprojekte & 87 & 1185 & 13.62 \\
\hline Sosialiseringsaktiwiteite & 26 & 331 & 12.73 \\
\hline Skakelbord & 9 & 190 & 21.11 \\
\hline Vervoer & 4 & 90 & 22.50 \\
\hline Nutsman & 2 & 135 & 67.50 \\
\hline Kafeteria & 2 & 442 & 221.00 \\
\hline Naaldwerk & 6 & 72 & - \\
\hline TOTALE AANTAL URE & - & 5113 & $\mathbf{1 7 . 2 2}$ \\
\hline GEMIDDELDE AANTAL URE & - & - & \\
\hline
\end{tabular}


Deelnemers is by meer as een aktiwiteit betrokke; daarom is die totaal in hierdie geval groter as die totale aantal deelnemers. Vir die verslagtydperk 1 April 2007 tot 31 Maart 2008 (Potchefstroom Dienssentrum vir Bejaardes, 2008b) is die gegewens, soos in Tabel 3 uiteengesit, uit die Besigheidsplan (2007/2008) verkry. Die totale aantal afgetrede vrywilligers ouer as 60 jaar wat by die dienssentrum betrokke is, is 132 . Uit bogenoemde tabel blyk dit dat die twee vrywilligers wat by die kafeteria betrokke is, elk 221 uur gewerk het, die nutsmanne 67.5 uur en diegene by die departement maatskaplike werk met die derde meeste aantal ure, naamlik 33.6. Die rede waarom die vrywillige ure van bedrywighede so wesenlik verskil, is die feit dat sekere aktiwiteite daagliks plaasvind en vrywilligers benodig en ander dienste slegs weekliks of kwartaalliks.

TABEL 4

\section{WYSE/S WAAROP DIE DEELNEMERS BY POTCHEFSTROOM DIENSSENTRUM VIR BEJAARDES BETROKKE IS}

\begin{tabular}{|l|c|c|l|c|c|}
\hline Fondswerwingsprojekte & 17 & $23.61 \%$ & Spyseniering & 17 & $23.61 \%$ \\
\hline Komiteelid & 8 & $11.11 \%$ & Administratief & 8 & $11.11 \%$ \\
\hline Maatskaplike werk & 5 & $6.94 \%$ & Tweedehandse winkel & 4 & $5.56 \%$ \\
\hline Beheerraad & 4 & $5.56 \%$ & Aktiwiteitsleier & 3 & $4.17 \%$ \\
\hline Voertuigbestuurder & 2 & $2.78 \%$ & Naaldwerk & 2 & $2.78 \%$ \\
\hline Nutsman & 2 & $2.78 \%$ & Ander & 0 & $0 \%$ \\
\hline
\end{tabular}

Hierdie tabel (Tabel 4) dui die wyses aan waarop die deelnemers aan hierdie ondersoek by die dienssentrum betrokke is. Weer eens is sommige deelnemers by meer as een komponent van vrywillige werk by die dienssentrum betrokke en kan die groter totaal in dié geval (72) daaraan toegeskryf word. Die meeste is egter by fondswerwingsprojekte en spyseniering van die dienssentrum betrokke. Spyseniering word vanuit die dienssentrum gedoen as 'n deurlopende fondsinsamelingsprojek. Die deelnemers het ook aangedui dat hulle gemiddeld agt uur per week beskikbaar is vir vrywillige werk by die dienssentrum. Le Roux (1985:118) se studie het getoon dat die gemiddelde werksure van die vrywilligers wat by haar navorsing betrokke was, 11 uur per week werksaam was. In die huidige ondersoek was die aantal ure dus minder en veral omdat die dienssentrum tans voldoende vrywilligers beskikbaar het en dit nie nodig is om sommige persone te veel in te span nie. Daar word daarteen gewaak om nie slegs van sekere bejaardes gebruik te maak nie en ook nie te veel take en verantwoordelikhede aan net enkeles op te dra nie.

\section{- MATE VAN VERANTWOORDELIKHEID}

Vrywilligers moet aanvaar dat hulle bykomstige opleiding of onderrig benodig, asook 'n keuringsproses moet deurloop, om vrywillige werk te kan doen ten einde daadwerklike bevrediging daaruit te kan put, nie kliënte skade aan te rig nie en ook binne die mandaat van die dienssentrum se werksaamhede te kan optree (Stim \& Warner, 2008: 87, 90). Deelnemers aan die ondersoek het soos volg reageer op die vraag oor die mate van verantwoordelikheid wat hulle bereid is om te aanvaar. Sewe persone, wat $16 \%$ verteenwoordig, het gesê dat hulle min verantwoordelikheid as vrywilliger wil aanvaar, 25 (57\%) persone is bereid om 'n redelike mate van verantwoordelikheid te aanvaar en 12 persone (27\%) sien kans vir baie verantwoordelikhede as vrywilliger. Daar kan gevra word wat die onderskeid is tussen min, redelik en baie verantwoordelikheid. Die vrywilligers wat betrokke is by spyseniering wat min verantwoordelikheid sou aanvaar, sou byvoorbeeld onder toesig van 'n personeellid of iemand in beheer help 
met die dek van tafels vir 'n funksie. Diegene wat redelike verantwoordelikheid sou aanvaar, is bereid om die verantwoordelikheid op hom/haar te neem om toe te sien dat al die tafels eenvormig en volgens etiket gedek is. Diegene wat kans sien vir baie verantwoordelikheid kan die totale versiering van die saal beplan, aankope doen en toesien dat die saal in die geheel netjies en gereed is vir die geleentheid.

Daar moet altyd in gedagte gehou word dat vrywilligers nie betaalde amptenare van die organisasie is nie en dat maatreëls ingestel moet word om hulle ook tegemoet te kom ten opsigte van wat hulle kan en wil doen. Todes (2003:79) wys verder daarop dat vrywillige werk so georganiseer behoort te word dat die vrywilliger 'n tyd lank afwesig kan wees en ook weer kan terugkom om take te hervat waar dit om die een of ander rede gestaak is.

\section{- VERWAGTINGE RAKENDE DIE DIENSSENTRUM EN PERSONEEL}

In die volgende tabel (Tabel 5) word die moontlike verwagtinge van die deelnemers aan die ondersoek uitgebeeld.

\section{TABEL 5}

MOONTLIKE VERWAGTINGE

\begin{tabular}{|l|c|c|c|c|}
\hline & JA & ONSEKER & NEE & TOTAAL \\
\hline $\begin{array}{l}\text { Uitnodiging na jaarlikse } \\
\text { bedankingsfunksie }\end{array}$ & $\begin{array}{c}25 \\
(56.82 \%)\end{array}$ & $\begin{array}{c}2 \\
(4.54 \%)\end{array}$ & $\begin{array}{c}17 \\
(38.64 \%)\end{array}$ & $\begin{array}{c}44 \\
(100 \%)\end{array}$ \\
\hline 'n Ete of verversings tydens diensbeurt & 12 & 4 & 28 & 44 \\
& $(27.27 \%)$ & $(9.09 \%)$ & $(63.64 \%)$ & $(100 \%)$ \\
\hline $\begin{array}{l}\text { Gratis vervoer van woning na } \\
\text { dienssentrum }\end{array}$ & 6 & 0 & 38 & 44 \\
& $(13.64 \%)$ & $(0 \%)$ & $(86.36 \%)$ & $(100 \%)$ \\
\hline Korting op lidmaatskap & 5 & 0 & 39 & 44 \\
& $(11.36 \%)$ & $(0 \%)$ & $(88.64 \%)$ & $(100 \%)$ \\
\hline $\begin{array}{l}\text { Bedankingsbriewe/oproepe na dienste } \\
\text { verrig }\end{array}$ & 3 & 1 & 40 & 44 \\
\hline Vervoertoelaag & $(6.82 \%)$ & $(2.27 \%)$ & $(90.91 \%)$ & $(100 \%)$ \\
\hline Korting op dienste & 3 & 0 & 41 & 44 \\
& $(6.82 \%)$ & $(0 \%)$ & $(93.18 \%)$ & $(100 \%)$ \\
\hline $\begin{array}{l}\text { Dienssertifikaat na bv. 1 jaar diens as } \\
\text { vrywilliger }\end{array}$ & 3 & 0 & 41 & 44 \\
\hline $\begin{array}{l}\text { Enige ander vorm van finansiële } \\
\text { vergoeding }\end{array}$ & $(6.82 \%)$ & $(0 \%)$ & $(93.18 \%)$ & $(100 \%)$ \\
\hline
\end{tabular}

Uit Tabel 5 kan afgelei word dat die deelnemers nie veel erkenning of vergoeding van die dienssentrum verwag nie. Die uitnodiging na die jaarlikse bedankingsfunksie vir alle dienssentrumlede is deur bykans $57 \%$ van die deelnemers as voldoende beloning vir hul dienste beskou, terwyl $27 \%$ 'n ete of verversings tydens hul diensbeurt sou waardeer. Van die kategorieë waarop 'n redelike "ja"-respons ontvang is, is gratis vervoer van woning na die dienssentrum (14\%) en korting op lidmaatskap (11\%). Bedankingsbriewe/oproepe na elke diens wat verrig is, 'n vervoertoelaag, korting op dienste en 'n dienssertifikaat na afloop van byvoorbeeld een jaar diens, het minder as 'n $10 \%$ "ja"-respons ontlok. Enige ander vorm van finansiële vergoeding het 'n besliste "nee"-respons tot gevolg gehad.

\section{- DIE BETEKENIS VAN VRYWILLIGE WERK VIR DIE AFGETREDENE}

Vrywillige werk bied aan ouer persone die geleentheid om aktief in die gemeenskap betrokke te raak en betrokke te bly. 'n Dienssentrum bied benewens die geleentheid tot die lewering van 'n bydrae ook die geleentheid vir persoonlike ontwikkeling en groei. Opleidingskursusse vir 
vrywillige werkers oor die verwagtinge wat aan hulle gestel sal word, asook die geleenthede wat aan hulle gebied word om nuwe vaardighede aan te leer is belangrik. Verstandelike stimulering is belangrik vir die instandhouding van algemene gesondheid van ouer persone. Hulle kan hul vreugdes en hul agtergrondgeskiedenis met 'n heel nuwe gehoor deel en nuwe vriendskappe sluit. Vrywillige werk kan dus 'n volkome nuwe betekenis aan die lewe gee. Die voordeel van vrywillige werk lê juis in die feit dat jy 'n keuse kan uitoefen oor watter werk jy wil doen, die hoeveelheid tyd wat jy daarvoor beskikbaar wil stel en dat jy steeds die bevrediging kan smaak met die wete dat jy 'n verskil in iemand anders se lewe maak (Daries, 1999).

Kulik (2006), Le Roux (1985:119) en Potchefstroom Dienssentrum vir Bejaardes (2008a) meld dat die betekenis van vrywillige werk vir afgetredenes dikwels in die volgende motiewe gesetel is, naamlik om naastediens te betoon sonder direkte vergoeding, die uitlewing van godsdienstige waardes, die uitbouing van die gemeenskap, konformering aan die norme van die gemeenskap, die vul van vryetyd, persoonlike erkenning, persoonlike ontwikkeling en die verbreding van horisonne. Voeg hierby ook die deel van ervaring.

Op 'n kwalitatiewe vraag wat die afgetredene se betrokkenheid as vrywilliger vir hom/haar beteken, kan die volgende aangehaal word:

- "Ek het tuisgekom en hier het my lewe na aftrede begin. Ek weet nou waar ek nog baie jare aktief betrokke kan wees en wat my doel en passie is: die dienssentrum!"

- "Die aansluiting as lede van die dienssentrum was die begin van 'n opwindende tydperk in ons lewe. My vrou en ek kon 'n bydrae lewer in die Mooirivierklub en in die Beheerraad. Vir ons was dit 'n verrykende ervaring en was dit so aangenaam om saam die dienssentrum te sien groei."

- "Om behulpsaam te wees met die voorbereiding van funksies is 'n manier om diens te lewer en konstruktief besig te wees. Om saam met ander lede te werk leer mens mekaar beter ken. Potchefstroom is voorwaar gelukkig om so 'n besondere sentrum te hê."

- "Die dienssentrum is 'n veilige hawe waarin jou lewensboot op sy laaste reis kan anker gooi."

- "Die sekuriteit van mense wat omgee en met liefde versorg, is die droom van elke ouerwordende persoon en gee sin aan die lewe."

- "Sluit aan by die dienssentrum, maak nuwe vriende en bly jonk."

Terwyl sommige van die motiewe fokus op maatskaplike bewustheid om ander te help, is ander weer daarop ingestel om in persoonlike behoeftes te voorsien. Motiewe, soos om nuwe verhoudings met mense op te bou en deel van die gemeenskap te wees is ook opgemerk (Chapman, 1985). Een van die basiese behoeftes van die mens is om êrens tuis, welkom en nodig te voel. Dit is ook goed om te weet dat hulle bevrediging daaruit put en dat hulle dit as 'n aangename en goeie tydverdryf beskou.

\section{BESPREKING}

Met betrekking tot die profiel van 'n afgetrede vrywilliger soos by hierdie betrokke organisasie gevind is, kan aangedui word dat deelnemers aan hierdie ondersoek ook in hul jonger dae in hul gemeenskappe betrokke was en dit nou voortsit in die aktiwiteite van die dienssentrum. Feitlik een derde van die deelnemers $(32 \%)$ was alreeds ten tye van die ondersoek tussen 6 en 10 jaar lank as vrywilliger by die dienssentrum betrokke. Uit die ondersoek was dit ook duidelik dat die deelnemers aan die ondersoek, net soos die totale aantal vrywilligers van die dienssentrum, by meer as een diens betrokke is. Die 44 deelnemers was by 72 dienste betrokke, wat neerkom 
op 'n gemiddeld van 1.64 dienste per persoon. Sewe-en-vyftig persent van die deelnemers was bereid om 'n redelike mate van verantwoordelikheid te aanvaar.

Uit die ondersoek was dit duidelik dat die deelnemers nie veel erkenning of vergoeding vir hul dienste verlang nie. Die meeste $(57 \%)$ deelnemers sou as beloning steeds 'n uitnodiging na die jaarlikse bedankingsfunksie vir alle dienssentrumlede ontvang, terwyl $27 \%$ 'n ete of verversings tydens hul diensbeurt sou waardeer. Die betekenis wat vrywillige werk vir deelnemers aan hierdie ondersoek ingehou het, kom neer op 'n hulpmotief om bejaardes te help wat dit benodig, om hulleself te verryk, om nuwe vriendskapsverhoudings te sluit, om deel van die gemeenskap uit te maak en om goeie vryetydsbesteding te geniet.

Vrywilligers is dikwels nie bereid om hulle oor lang periodes te bind nie, of hulle vind na 'n tydperk van diens dat hulle nie gelukkig is in hul werk nie en onttrek hulle dan. Indien afgetredenes met hul kennis en kundigheid op georganiseerde wyse as vrywilligers by niewinsgewende organisasies betrokke raak, kan dit bydra tot 'n meer koste-effektiewe funksionering van die organisasie. As die aangeduide 5113 ure van vrywilligers van Potchefstroom Dienssentrum vir Bejaardes byvoorbeeld in rand en sent omgesit sou moes word, sou dit daarsonder onmoontlik wees om al die waardevolle dienste te lewer, want dit sou vir die dienssentrum finansieel nie haalbaar gewees het nie.

Dit is wesenlik belangrik dat vrywilligers gekeur moet word vir die taak wat verrig moet word en daarna deeglik opgelei moet word vir die spesifieke funksie wat uitgevoer moet word en dat opleiding ten minste sesmaandeliks herhaal moet word. Die passing van die vrywilliger by die afdeling en die afdelingshoof moet deeglik in ag geneem word. Die organisasie moet voortdurend in gedagte hou dat vrywilligers nie betaalde amptenaar van die organisasie is nie; daarom gekoester moet word vir die bydrae wat hulle lewer.

\section{AANBEVELINGS}

- Daar word aanbeveel dat organisasies wat van vrywilligers gebruik maak, die profiel van hul vrywilligers wetenskaplik moet bepaal en vasstel wat hul verwagtinge van die organisasie is en in watter mate die kundigheid van vrywilligers tot voordeel van die organisasie benut kan word.

- Keuring en opleiding van vrywilligers kan dienssentrums in staat stel om die gehalte van dienslewering te verhoog en kan ook meebring dat die vrywilligers meer bevrediging uit hul werksverrigting put. Die vrywilligers moet bevrediging uit hul betrokkenheid put om te verseker dat hul dienste behou word, en die manier waarop hulle ingeskakel word, gaan bepaal of hulle tevredenheid daaruit put al dan nie (Le Roux, 1985:111, 139).

- Nie-winsgewende organisasies moet al hul dienste en aktiwiteite in oënskou neem en besluit waar hulle die hulp van vrywillige werkers kan benut ten einde die werksdruk van die betaalde personeel te verlig.

- Deur oor 'n databasis van vrywilligers te beskik word die nie-winsgewende organisasie in staat gestel om te weet hoedanig die vrywilligerkorps daar uitsien, wat hul belangstellings en verwagtinge is en hoeveel tyd elkeen tot hulle beskikking het.

- Daar word aanbeveel dat 'n program ontwikkel moet word ten einde personeel op te lei om vrywilligers by die dienssentrum se aktiwiteite te betrek, hulle in te skakel en hulle te bestuur. 
- 'n Bemagtigingsprogram vir vrywilligers behoort van tyd tot tyd vir nuwe en bestaande vrywilligers aangebied te word. Sodoende kan vrywilligers toegerus word op die spesifieke take wat op hulle wag en kan hulle doeltreffender benut word.

- Afgesien van 'n formele bemagtigingsprogram vir afgetrede vrywilligers, behoort gereelde verrykingsgeleenthede vir die vrywilligers aangebied te word.

- 'n Jaarlikse bedankingsfunksie vir vrywillige werkers behoort gekoester te word. Tydens hierdie geleentheid behoort terugvoering gegee te word oor die jaar se dienste en aktiwiteite waarby vrywillige werkers betrokke was.

\section{SAMEVATTING}

In hierdie artikel is gefokus op die profiel van die afgetrede vrywilliger van hierdie spesifieke nie-winsgewende organisasie. Die sake wat by die profiel ter sprake gekom het, is geslag, ouderdom, taal, gesin van herkoms, kinders, betrokkenheid in jonger jare, beroep voor aftrede en tydperk van betrokkenheid by die dienssentrum. Die terreine waarop vrywilligers betrokke is, is behandel, waarna die mate van verantwoordelikheid wat hul bereid is om te aanvaar bespreek is. Die verwagtinge van vrywilligers van die dienssentrum en die betekenis van vrywillige werk vir die afgetredene is ook behandel. Dit het ook duidelik geblyk dat, indien daar aan die verwagtinge van vrywilligers voldoen word, hulle 'n langer termyn by die niewinsgewende organisasie betrokke sal bly.

Dit is belangrik om die vrywilliger te ken, vrywilligers te keur en behoorlik op te lei in die take wat hul moet aanpak en die regte passing met betrekking tot dienslewering te bewerkstellig. Indien al hierdie aspekte by die benutting van afgetrede vrywilligers in ag geneem word, sal dit 'n positiewe uitwerking op al die betrokke partye hê en tot beswil van die funksionering van die nie-winsgewende organisasie bydra. Vrywillige werkers verlig beslis die werksdruk van die betaalde personeel en lewer kosbare diens aan die bejaarde lede van die dienssentrum (en aan hulleself).

\section{BIBLIOGRAFIE}

BURNS, N. \& GROVE, S.K. 2005. The practice of nursing research: conduct, critique \& utilization. Texas: Saunders.

CHAPMAN, T.H. 1985. Motivation in university student volunteering. In: MOORE, L.F. (ed) Motivating volunteers. Vancouver, BC: Vancouver Volunteer Center: 231-242.

CRESWELL, J.W. 2009. Research design: qualitative, quantitative and mixed methods approaches. London: Sage Publications.

DARIES, J. 1999. Older volunteers - a vital link in community care. National Conference 11-13 August 1999. The South African Council for the Aged.

DEPARTMENT OF SOCIAL DEVELOPMENT. 2005. South African policy for older persons. Pretoria: Government Printer.

ECKLEY, S. 2007. Aktiewe veroudering - hoe raak dit ouer mense. Voordrag gelewer as deel van die Expo 50 Plus op 1 Oktober 2007. Pretoria. (Ongepubliseer)

GOLDEN, G.K. 1991. Volunteer counselors: an innovative economic response to mental health service gaps. Social Work, 36(3):230-232. 
GREEFF, M. 2005. Information collection: interviewing. In: DE VOS, A.S., STRYDOM, H., FOUCHÉ, C.B. \& DELPORT, C.S.L. Research at grass roots: for the social sciences and human service professions. Pretoria: Van Schaik Publishers: 286-313.

GRINNELL, R.M. \& UNRAU, Y.A. 2008. Social work research and evaluation: foundations of evidence-based practice. London: Oxford University Press.

HASKI-LEVINTHAL, D. 2001. Ahat ultamid: Hatmada veneshira shel mitnadvim bemerkaz lenifga'ei tkifa minit beyerushalayim [Once and for all: Longevity and attrition of volunteers at a sexual assault crisis centre in Jerusalem]. The Paul Baerwald School of Social Work. The Hebrew University of Jerusalem. (Unpublished MA Thesis)

KRÜGER, E. 2008. Vrywillige werkers in bejaardesorg. Plus, 50(3/4):18-20.

KULIK, L. 2006. Burnout among volunteers in the social services: The impact of gender and employment status. Journal of Community Psychology, 34(5):541-561. [Online] Available: www.interscience.wiley.com.

LEESON, G.W. 2006. Attitudes to ageing and old age. The Danish Longitudinal Future Study. Oxford: Oxford University Press.

LEHRMAN-ABARBANEL, M. 1994. Havayat omes rigshi etzel toranei eran [Experience of emotional overload among crisis hotline workers]. The Paul Baerwald School of Social Work. The Hebrew University of Jerusalem. (Unpublished MA Thesis)

LE ROUX, A.M. 1985. Die inskakeling van vrywillige werkkragte by dienssentrums vir bejaardes. Port Elizabeth: Universiteit van Port Elizabeth. (MA(MW) Verhandeling)

MERTENS, D.M. \& GINSBERG, P.E. 2009. The handbook of social research ethics. Washington: Sage Publications.

MITCHELl, M. \& JOLlEY, J. 2001. Research design explained. New York: Harcourt College Publications.

MYBURGH, M. 1999. Voorbereiding vir aftrede: 'n bedryfsmaatskaplike werk ondersoek. Pretoria: Universiteit van Pretoria. (MA(MW) Verhandeling)

NEUMAN, W.L. 2006. Social research methods: qualitative and quantitative approaches. New York: Allyn and Bacon.

NTUSI, N. \& FERREIRA, M. 2004. South African doctors and elderly patients. Bold, 15(1):3-13.

POGGENPOEL, M. 1998. Data analysis in qualitative research. In: DE VOS, A.S., STRYDOM, H., FOUCHÉ, C.B., POGGENPOEL, M. \& SCHURINK, E.W. Research at grass roots: a primer for the caring professions. Pretoria: J.L. van Schaik Publishers: 334353.

POTCHEFSTROOM DIENSSENTRUM VIR BEJAARDES. 2008a. Jaarverslag. Potchefstroom. (Ongepubliseer.)

POTCHEFSTROOM DIENSSENTRUM VIR BEJAARDES. 2008b. Besigheidsplan. Potchefstroom. (Ongepubliseer)

POTCHEFSTROOM DIENSSENTRUM VIR BEJAARDES. 2008c. Mondelinge mededeling van die departementshoofde van Potchefstroom Dienssentrum vir Bejaardes aan die outeur. Potchefstroom.

RÖRICH, W.B.K. 1992. Die ontwikkeling en evaluering van primêre voorkomingsprogramme vir kindermishandeling deur die benutting van die vrywilliger by die 
Witbankse Kindersorgvereniging. Pretoria: Universiteit van Pretoria. (MA(MW) Verhandeling)

ROUX, A.A. 2008. Opleidingskursus vir vrywilligers van Potchefstroom Dienssentrum vir Bejaardes. Voordrag gelewer as deel van die opleidingskursus vir vrywilligers betrokke by maatskaplike werk op 30 Januarie 2008. Potchefstroom. (Ongepubliseer)

RUBIN, A. \& BABBIE, E.R. 2005. Research methods for social work. London: Thomson Brooks/Cole.

SLABBERT, L. 1989. Die benutting van vrywilligers binne 'n organisasie soos Nimro. Pretoria: Universiteit van Pretoria. (MA(MW) Verhandeling)

STATISTICS SOUTH AFRICA. 2001. Census. [Online] Available: http://www.statssa.gov.za/ census01/Census/Dialog/Saveshow.asp [Accessed: 29/03/2008]

STIM, R. \& WARNER, R. 2008. Retire happy: what you can do now to guarantee a great retirement. Berkeley: Nolo.

STOKER, D.J. 1985. Sampling. Personal communication to the author. Pretoria: Human Sciences Research Council.

STRYDOM, H. 2005a. Sampling and sampling methods. In: DE VOS, A.S., STRYDOM, H., FOUCHÉ, C.B. \& DELPORT, C.S.L. Research at grass roots: for the social science and human service professions. Pretoria: Van Schaik Publishers: 192-204.

STRYDOM, H. 2005b. Ethical aspects of research in the social sciences and human service professions. In: DE VOS, A.S., STRYDOM, H., FOUCHÉ, C.B. \& DELPORT, C.S.L. Research at grass roots: for the social science and human service professions. Pretoria: Van Schaik Publishers: 56-70.)

TODES, A. 2003. Peer-caring among senior citizens at fifteen subsidised service centres in the Cape Town metropole. Cape Town: University of Cape Town. (MA(MW) Verhandeling) VAN DEN HEEVER, J. 1990. Die doel en waarde van 'n dienssentrum. Senior Nuus, 23(1):12.

VAN DER LINDE, A. 2007. Aktief en positief? Dan leef jy langer en lekkerder. (In IntegriSure for Insurance, Aktiewe veroudering - 'n uitdaging vir ons tyd: 2007). Simposium georganiseer deur Expo 50 Plus. Pretoria.

VAN DER LINDE, H.W.G. 1996. Die Suid-Afrikaanse Raad vir Bejaardes. Jaarverslag. Kaapstad.

VAN ZYL, C.C. 1992. 'n Maatskaplikewerk-model vir aftredebeplanning. Bloemfontein: Universiteit van die Oranje Vrystaat. (MSc Verhandeling)

WHEELER, J.A., GOREY, K.M. \& GREENBLATT, B. 1998. The beneficial effects of volunteering for older volunteers and the people they serve: a meta-analysis. International Journal of Aging and Human Development, 47(1):69-79.

Me Sanet Jansen van Rensburg, Potchefstroom Dienssentrum vir Bejaardes; Prof Herman Strydom, Skool vir Psigososiale Gedragswetenskappe: Vakgroep Maatskaplike Werk, Potchefstroomkampus van die Noordwes-Universiteit, Potchefstroom, SuidAfrika. 